\title{
5. Local housing standard for a living wage
}

\section{PART I. BACKGROUND AND CONCEPTUAL FRAMEWORK}

Housing is almost always the second biggest expense for workers in developing countries (after food) and the biggest expense for workers in developed countries. Adequate housing is considered to be a right by the international community. For these reasons it is important to ensure that a living wage is high enough for workers to be able to afford decent housing. With this in mind, our living wage methodology estimates housing costs separately based on a normative standard of decent, healthy housing. Two steps are used to estimate housing costs.

The first step creates a normative standard for decent housing for a family in a given location based on international principles and local conditions. The second step estimates the cost of local housing that meets the local decent housing standard. This cost is estimated primarily through a local housing market survey that includes visits to homes in neighborhoods where workers live.

\subsection{Advantages of Approach Used to Estimate Housing Costs}

In contrast to our methodology, the most common methodologies for estimating living wages and poverty lines for developing countries do not ensure that workers earning a living wage would be able to afford decent housing, because these common methodologies estimate all non-food expenses (including housing) in one go based in large part on secondary household expenditure survey data. For example, if food expenditure is $50 \%$ of all expenditures according to a household survey, non-food costs would be assumed to be equal to food cost. If food expenditure is $33 \%$ of all expenditures, non-food costs would be assumed to be twice the cost of food. In these common methodologies, housing costs are subsumed within non-food costs. Problems with this common approach include: 
- No attention is given to ensuring that funds for non-food needs are sufficient to meet minimum standards. This includes housing.

- Funds will not be sufficient for decent housing for a family when many people currently live in substandard housing which is reflected in household expenditure statistics.

- National statistical offices differ in how they measure housing expenditures. Nearly half of countries in the world assume that owner-occupied housing has no cost or user value. This means that expenditure for housing according to household expenditure statistics is much too low in close to half of all countries. Thus, it is not possible to get a good estimate of housing costs by relying on national statistics alone, especially in countries that do not include the value or user cost of owner-occupied housing in their statistics.

Our approach has several advantages compared to the common methodology discussed above.

- Our approach ensures that sufficient funds are available for workers to be able to afford decent housing for their family and so avoids the possibility of replicating the substandard housing found in many developing countries today.

- Our approach avoids the problem of relying on household expenditure data, which is especially important in the many countries where national statistical offices do not measure the value or cost of owneroccupied housing.

- By measuring local housing costs separately, our approach allows separate estimates of living wages for different areas within a country, because housing costs are the most important reason for differences in living costs between rural and urban areas and between big and small cities.

\section{PART II. PRINCIPLES AND CHARACTERISTICS OF DECENT HOUSING FOR A LIVING WAGE}

The normative standard for decent housing is established based on:

- Principles of minimum standards for housing from international conventions, international organizations, and standard setting organizations

- Housing standards set by government

- Housing conditions in a location 
International principles provide broad guidelines, indicating, for example, that acceptable housing needs to have a durable structure, adequate sanitation, and safe water. They provide the principles and general characteristics of decent housing. Information on local housing conditions (e.g. percentage of dwellings made from various building materials and percentage of dwellings with various types of toilets, and housing standards of government authorities) identify what would be acceptable for decency in a location for each housing principle and characteristic. For example, while international principles indicate that safe water is required, information on local housing conditions would help determine whether for decency safe water needs to be piped indoors, piped nearby the house, or drawn from a nearby well. While international principles require adequate sanitary facilities, information on local housing conditions help determine whether the toilet needs to be a flush toilet or a pit latrine, as well as whether toilet facilities can be shared and still be considered decent. However, not having access to safe water near the house or not having access to decent sanitary facilities - which might be typical in some locations - would violate international principles of healthy housing and therefore could never be considered acceptable.

\subsection{Review of International Housing Standards}

We begin discussion of appropriate standards for decent and healthy housing with a review of international housing conventions, standards, and recommendations. This includes the right to adequate housing (Section 5.2.1) and principles for adequate housing included in international conventions and recommendations (Section 5.2.2).

\subsubsection{Right to adequate housing}

Adequate housing is considered a right according to the international community (italics added for emphasis). ${ }^{1}$

- Article 25 of the 1948 Universal Declaration of Human Rights states that: 'Everyone has the right to a standard of living adequate for health and well-being for himself and for his family, including food, clothing, housing and medical care and necessary social services.'

- Article 11(1) of the 1966 International Covenant on Economic, Social, and Cultural Rights 'recognize the right of everyone to an adequate standard of living for himself and his family, including adequate food, clothing and housing.'

- The 1944 Declaration of Philadelphia of the International Labour Organization (ILO), which is an annex to its constitution, 'recognizes 
the solemn obligation of the International Labour Organization to further among the nations of the world programs which will achieve: ... III (i) the provision of adequate nutrition, housing and facilities for recreation and culture.'

Many countries include housing rights in their constitutions and laws which are often modeled after international standards and principles (Thiele, 2002).

\subsubsection{Principles for adequate housing in international conventions and recommendations and according to international organizations}

International organizations have developed principles of adequate, decent and healthy housing. This includes the International Covenant on Economic, Social and Cultural Rights (United Nations, 1966), ILO Recommendation No. 115 Concerning Workers' Housing (1961), World Health Organization Principles of Healthy Housing (1989), and UNHabitat $(2009,2013)$. For detailed descriptions of the definitions and principles of these, see Appendix 5.1. Table 5.1 summarizes this.

Although these definitions and principles emphasize different aspects of decency, there is a great deal of overlap. Acceptable/adequate housing needs to have the following attributes:

- Durable structure

- Sufficient living space

- Access to safe water

- Access to sanitary toilet and washing facilities

- Adequate lighting

- Adequate ventilation

- Adequate food storage

- Separation from animal quarters

- Protection from cold, damp, heat, rain, wind or other threats to health, structural hazards, and disease vectors

Acceptable housing cannot be located in:

- Slum $^{2}$

- Unsafe area

- Hazardous area

- Area without refuse disposal

- Area without site drainage

- Area lacking emergency services 


\section{Table 5.1 Housing standards in international conventions and recommendations ${ }^{a}$}

\begin{tabular}{|c|c|c|c|}
\hline Standard & $\begin{array}{l}\text { International } \\
\text { Covenant on } \\
\text { Economic, } \\
\text { Social and } \\
\text { Cultural } \\
\text { Rights }\end{array}$ & $\begin{array}{l}\text { ILO Recommen- } \\
\text { dation No. } 115 \\
\text { Concerning } \\
\text { Workers' } \\
\text { Housing }\end{array}$ & $\begin{array}{l}\text { WHO healthy } \\
\text { housing }\end{array}$ \\
\hline Safe water ${ }^{b}$ & $\checkmark$ & $\checkmark$ & $\checkmark$ \\
\hline $\begin{array}{l}\text { Sanitation/toilet \& } \\
\text { sewage disposal }\end{array}$ & $\checkmark$ & $\checkmark$ & $\checkmark$ \\
\hline Sufficient living space ${ }^{b}$ & $\checkmark$ & $\begin{array}{l}\text { Persons per } \\
\text { room and/or } \\
\text { floor area }\end{array}$ & $\begin{array}{l}\text { Persons per } \\
\text { room }\end{array}$ \\
\hline $\begin{array}{l}\text { Durable structure } \\
\text { (protection against } \\
\text { elements) }^{\mathrm{b}}\end{array}$ & $\checkmark$ & $\checkmark$ & $\checkmark$ \\
\hline $\begin{array}{l}\text { Good condition \& } \\
\text { state of repair }{ }^{b}\end{array}$ & $\checkmark \mathrm{e}$ & $\checkmark \mathrm{f}$ & $\checkmark$ \\
\hline Physical safety & $\checkmark$ & & $\checkmark$ \\
\hline Adequate ventilation & & $\checkmark$ & $\checkmark$ \\
\hline Adequate lighting & $\checkmark$ & $\checkmark$ & $\checkmark$ \\
\hline Safe food storage & & $\checkmark$ & $\checkmark$ \\
\hline Washing facilities & $\checkmark$ & $\checkmark$ & $\checkmark$ \\
\hline $\begin{array}{l}\text { Separation from animals } \\
\text { Electricity }\end{array}$ & & $\checkmark$ & $\checkmark$ \\
\hline No site hazards $\mathrm{b}, \mathrm{c}$ & $\begin{array}{l}\text { Drainage } \\
\text { Polluted }\end{array}$ & Earthquake & Many ${ }^{d}$ \\
\hline $\begin{array}{l}\text { Refuse/solid waste } \\
\text { disposal }\end{array}$ & $\checkmark$ & $\checkmark$ & $\checkmark$ \\
\hline Emergency services & $\checkmark$ & & $\checkmark$ \\
\hline Protection from elements & $\checkmark \mathrm{e}$ & $v^{f}$ & $\checkmark$ \\
\hline
\end{tabular}

Notes:

a UN-Habitat urban slum housing definition is not included in this table, because it includes only five elements: 'inadequate access to safe water; inadequate access to sanitation and other infrastructure; poor structural quality of housing; overcrowding; insecure residential status' in addition to security of tenure.

b Element included in UN-Habitat definition of urban slum housing.

c According to UN-Habitat the following locations should be considered as hazardous 'housing in geologically hazardous zones (landslide/earthquake and flood areas); housing on or under garbage mountains; housing around high-industrial pollution areas; housing around other unprotected high-risk zones (e.g. railroads, airports, energy transmission lines)' (UN-Habitat, 2003, p. 12).

d WHO indicates the following site hazards: earthquakes, hurricanes, wind, noise, pollution, floods, and landslides. 
Table 5.1 (continued)

e Implied by 'protection from cold, damp, heat, rain, wind or other threats to health, structural hazards, and disease vectors' (International Covenant on Economic, Social, and Cultural Rights, 1966).

f Implied by 'protection against heat, cold, damp' (ILO Recommendation No. 155).

Sources: International Covenant on Economic, Social and Cultural Rights (1966), ILO Recommendation No. 115 Concerning Workers' Housing (1961), WHO (1989), UN-Habitat (2003).

\subsubsection{Rural and urban differences}

Although distinctions between rural and urban areas are not explicitly mentioned in the above principles, it is clear that some housing standards can be relaxed in rural areas while maintaining the principles of healthy housing. Population density in urban areas means that community services (e.g. refuse collection, street lighting, and public safety) are more important in urban areas than in rural areas.

\subsection{Housing Standards of Certifying and Standard Setting Organizations}

Standard setting organizations have codes of practice that companies need to meet to be certified. These codes of practice include housing standards. The Sustainable Agricultural Network/Rainforest Alliance (2005) standard is an example:

Housing provided by the farm for permanent or temporary workers living there must be well-designed, built and maintained to foster good hygienic, health and safety conditions. Living quarters must be separated from production areas. In absence of applicable laws the following elements and characteristics apply:

- Dormitories must be constructed with wooden floors above the ground or floors made from asphalt or concrete, roofs in good condition without leaks, and with appropriate ventilation and lighting.

- Ceiling must not be lower than 2.5 meters at any point.

- Five square meters of space per person in sleeping areas.

- Heating for cold climates.

- One toilet for every 15 persons; one urinal for every 25 men.

- One shower per ten persons, separated by gender.

There is some consensus across the GLWC members as regards elements of acceptable housing. At the same time, these standards are less comprehensive in scope than those of international organizations, probably because some GLWC members are concerned with farm dormitory accommodation. Elements of acceptable housing that appear in the codes of practice of at least half of GLWC members are: 
- Good condition/clean

- Potable/safe water

- Sanitary facilities

- Security/safety

- Appropriate ventilation

- Bathing/shower facilities

\subsection{Housing Conditions in Europe and United States over Past 75 Years}

It is useful to be aware that housing conditions in Europe and the United States 75-100 years ago when they were much poorer, were similar to housing conditions in many developing countries today. In the United States in the 1930s, for example, housing conditions were poor indeed in some parts of the South. Less than $1 \%$ of houses had a private flush toilet or running water among Knott County, Kentucky, farms; $49 \%$ of houses in Charleston, South Carolina, and $21 \%$ of houses in Atlanta, Georgia did not have an indoor private toilet; $50 \%$ of houses in Charleston, and $29 \%$ of houses in Atlanta did not have electricity (Williams et al., 1937).

\subsection{Measurement of Adequate Living Space}

Two approaches are used to measure whether a dwelling has adequate living space. One approach uses number of square meters or square feet of living space. The other approach uses number of rooms or bedrooms. ${ }^{3} \mathrm{We}$ feel that for a living wage, the preferred approach for measuring adequate living space is the number of square meters or square feet of living space. The International Comparison Program (ICP) of the World Bank reached the same conclusion: 'The best quality measure [of housing] is the total surface space of dwellings' (Blades, 2010), and 'The ICP manual and other documents of the 2005 ICP sought square meters of internal living space as the preferred indicator' (Heston, 2013, p. 325).

On the other hand, because of its simplicity, number of rooms or number of persons per room is the easier of the two approaches to use and it was used to measure overcrowded housing roughly 100 years ago. 'The most widely adopted [measure of crowding] because it is at once simple and significant, is based on the number of persons living in one and the same dwelling: the number of persons per room' (ILO, 1928). Roughly at the same time, an ILO Committee of Statistical Experts Resolution (1935) recognized that 'Rents distinguished only according to number of rooms do not form a sufficient basis for comparison. The Committee accordingly recommends that particulars for the rent of each category of dwellings 
should be accompanied by an indication of total floor space ... showing the levels of rent expressed (a) per room and (b) per square meter of total floor space' (ILO, 1935, p. 113).

A major problem with a number of rooms or persons per room definition for measuring local housing costs for a living wage is that room sizes are quite variable around the world. For example, government low income housing in India includes very small rooms of 9-11 square meters (Uttar Pradesh Housing and Development Board, 2014). In contrast, floor plans for affordable housing in South Africa include one large room of 30-45 square meters (Moolla et al., 2011) - with occupants frequently dividing this large room into smaller spaces for privacy using high dressers, curtains, etc. Another problem with the number of rooms definition is that rent is related more to amount of floor space than to number of rooms. A third disadvantage is that the number of rooms measure is so discrete in nature that it cannot be changed smoothly as a country develops and incomes increase. This is attested to by the fact that the definition of overcrowding established by the United Kingdom in 1935 continues to be law in the United Kingdom today (House of Commons Library, 2011). In contrast, the amount of living space for acceptable housing can be increased less abruptly with economic development. Malaysia and China provide good examples of this. Minimum floor space for public housing in Malaysia (Hadi, 2014) increased from 37.1 square meters (1956-1981) to 49.2 square meters (1982-1996), 52 square meters (1997-1998), and 60.3 square meters (1999-present). In Shenzhen, China, gross floor space for low rent housing went from 45 square meters in 2008 to 50 square meters for 2-3 person households and 65 square meters for 4+ person households in 2014 (Wang et al., 2016). An added advantage of using a square meters of living space standard is that in locations where it is difficult to find acceptable housing with the required amenities and somewhere around the number of square meters required, it is possible to estimate rent for acceptable housing with the required number of square meters by regressing rent per square meter on number of square meters of floor space. We used this approach for a living wage study in Vietnam (Anker and Anker, 2015) and Wang et al. (2016) used this approach for a living wage study for Shenzhen, China.

These two approaches for measuring adequate living space for a living wage are discussed below. Both are legitimate approaches. Although we prefer the number of square meters or feet approach, the number of rooms approach is also worth using in many situations. 
Table 5.2 Definition of overcrowding in housing used in Europe 100 years ago

\begin{tabular}{ll}
\hline Location & $\begin{array}{l}\text { Definition of overcrowding } \\
\text { (persons per room) }\end{array}$ \\
\hline Finland 1919 & $\geq 3$ per room \\
Prague 1921 & $>2$ per heated room \\
France 1901-1911 & $>2$ per room \\
Copenhagen 1921 & $>2$ per room \\
Fredericksburg 1921 & $>2$ per room \\
Norway 1920 & $>2$ per room \\
Warsaw 1919 & $>2$ per room \\
\hline
\end{tabular}

Source: ILO (1928).

\subsubsection{Number of persons per room (or per bedroom)}

In the 1920s when ILO, governments and researchers became interested in comparing living conditions across countries 'overcrowding' was the most common concept used for measuring housing quality. The typical definition of overcrowding at that time in Europe was more than two persons per room (Table 5.2). This is a more stringent definition than the more than three persons per room definition currently used by UN-Habitat for urban areas in developing countries. UN-Habitat changed to this definition of overcrowding not because it was preferable from a conceptual point of view, but because a more than two persons per room definition yielded what were felt to be uncomfortably high percentages of overcrowding. 'After observing the statistical distribution of more than two persons per room throughout the world, UN-Habitat revised its definition to three persons per room' (UN-Habitat, 2006, p. 70).

The United Kingdom still defines overcrowding as more than two persons per room. This means that at least two rooms that can potentially be used for sleeping purposes (e.g. bedroom, dining room, and living room) are required for a family of four, and three such rooms are required for a family of five. ${ }^{4}$ Other developed countries define overcrowding based on number of persons per bedroom to better reflect improved housing conditions in developed countries over the last 80 years. This includes Ireland, Canada and Australia (Ireland, Office of the Attorney General, 1966; Australian Bureau of Statistics. 2011). ${ }^{5}$ 


\subsubsection{Floor space}

5.5.2.1 Amount of floor space around the world The United Nations (2000) indicates average (median) floor space per person by development level, region and country based on information for 188 cities. It was 11.9 square meters for the world, 7.3 for least developed countries, 8.6 for Africa, 10.2 for Asia and Oceania (excluding Australia, New Zealand and Japan), 11.0 for Latin America and Caribbean and 21.3 for more developed regions. These data imply around the following number of square meters of floor space for a family of 4 persons: 29 (least developed countries), 35 (Africa), 41 (Asia and Oceania), 44 (Latin America and Caribbean), 48 (World), and 85 (more developed regions). According to EUROSTAT (2014), average (mean) space per dwelling was around 53 square meters (ranging from 34 to 69) for 11 former socialist countries in East and Central Europe and around 78 square meters (ranging from 63 to 100) for 18 other European Union countries. Floor space is higher still in the United States where households at the 20th percentile of the household income distribution had 28.8 square meters per person in 1985 and 33.5 square meters per person in 2005, implying around 115 and 134 square meters respectively for a lower income household of 4 persons (United States Department of Housing and Urban Development, 2007). The amount of floor space found in different regions and at different development levels implies somewhere around 35 square meters of floor space for low income countries (using median value for Africa as a proxy) and around 80+ square meters for high income countries (using European countries as a proxy).

\subsubsection{Amount of floor space for government supported low income and} affordable housing ${ }^{6}$ National, state, and city governments typically have housing departments and authorities that provide or subsidize affordable and/or low income housing. These programs are called by different names such as 'low rent housing,' 'low-cost housing,' 'affordable housing,' 'social housing,' and 'public housing,' but they all have the same purpose - to provide or encourage the building of low-cost housing. Guidelines are often provided along with floor plans. These represent what government feels is minimum acceptable housing. As Habitat for Humanity International (2008) put it: 'Each country has its own understanding of adequate housing, which may also vary within national boundaries.' Countries sometimes also have laws that specify minimum living space allowed for newly constructed flats and houses.

It is important to keep in mind that there is a difference between covered floor space (sometimes referred to as gross floor space or plinth area) and living space (sometimes referred to as carpet area or usable floor space). 
Floor area is 'the area contained within the outer surface of external walls of a building measured at each floor level' (Republic of Kenya, National Building and Planning Authority, 2009, p. A-23) while living space is 'the floor area of the usable rooms' (Bureau of India Standards, 2002, p. 1). Countries differ in what they include in covered area and living space. India, for example, includes in covered space $100 \%$ of the area of balconies and verandah protected by a roof and $50 \%$ of those not protected by a roof. India excludes from living space (called carpet area in India): verandahs, balconies, entrance halls or porches, bathrooms and WCs, and kitchens and pantries (Bureau of Indian Standards, 2002). Many other countries include kitchens and WCs and treatment of balconies and verandahs depends on climate and whether enclosed. In China, common areas such as elevators and stairwells are apportioned and counted as part of each apartment's living space. All of this means that the size of the difference between living space and covered space differs across countries. At a minimum, around $10 \%$ of space is lost to thickness of internal and external walls. ${ }^{7}$ How much more than $10 \%$ is lost depends on the floor plan, number of internal walls, and which areas are included or excluded when calculating living space. As a rule of thumb, we have found a $12 \%$ difference is generally a reasonable approximation, although we found this difference to be as high as $20 \%$ for Sri Lanka tea estate houses.

To get an idea of national standards for living space for countries at different development levels, we put together information on this for 16 countries (Table 5.3). Some of these are discussed below.

SOUTH AFRICA South Africa has laws and regulations concerned with adequate living space. South African Basic Conditions of Employment Act No. 75 for Farm Worker Section (Republic of South Africa, 1997, p. 8) indicates that it is acceptable to deduct the value of free accommodation from wages only when 'the house is not less than 30 square meters in size'. South Africa Housing Consumer Protection Measures Act of 1998 indicates that 'houses must be at least 30 square meters in size' (ETU, 2014). The South Africa government's Reconstruction and Development Programme (RDP) for 'low-cost' housing builds small houses consisting of one large room (Thale, 2001; Cox, 2008) that has 30-45 square meters of living space (Pottie, 2003) with typical RDP houses around 36 square meters (Moolla et al., 2011).

INDIA National and state governments in India have departments, authorities, and schemes concerned with provision of affordable housing. They set standards for living space to carry out their mandates. This includes federal Government of India Ministry of Housing and Urban Poverty Alleviation 
(JNNURM) (2013) and each state such as Maharashtra (Maharashtra Housing and Area Development Authority (MHADHA), 2014) and Uttar Pradesh (Uttar Pradesh Housing and Development Board (UPAVP), 2014), the two largest states in India. Amount of living space allowed is specified as a function of family income to ensure affordability with repayment of home loan not exceeding $30-40 \%$ of monthly income. Four income groups are used: (1) EWS (economically weaker section), (2) LIG (low income group), (3) MIG (middle income group), and (4) HIG (high income group). The living space standard used by these three Indian government authorities is similar. Living space for EWS housing is up to around 28 square meters (300 square feet). Living space for LIG housing - that we feel is relevant for a living wage estimate for urban workers in India since the living wage we estimated for Nagpur in 2013 fell within the LIG low income group (Anker and Anker, 2013) - ranged from around 28 square meters to around 48 square meters (around 36 square meters on average). ${ }^{8}$ Living space for the middle income group ranged from around 48-80 square meters and living space for the high income group was $80+$ square meters.

KENYA Republic of Kenya Ministry of Housing (2004, p. 9) considers urban 'low-cost housing' as 'comprising a minimum of two habitable rooms, cooking area and sanitary facilities, covering a minimum gross floor area of 40 square meters for each household.' It considers that 'urban middle-cost housing is covering a minimum gross floor area of 60 square meters.' This implies a minimum of around 36 square meters of living space for low-cost housing and a minimum of around 53 square meters of floor space for middle-cost housing (assuming inner and outer walls occupy 12\% of the gross floor space).

VIETNAM Article 47(2) of the 2015 Housing Law in Vietnam sets a minimum of 30 square meters and a maximum of 59 square meters for urban 'social housing.' Decree 99/2015 Article 6(2) states that new flats cannot be smaller than 30 square meters.

CHINA Government supported 'low rent' housing in Shenzhen, China, a major elite city in what is now an upper middle income country, included a maximum of 45 square meters of gross living space (around 40 square meters of living space) in 2008. This standard increased to 50 square meters (around 44 square meters of living space) in 2014 for 2-3 person households and 65 square meters (around 57 square meters of living space) for households with 4 or more persons (Wang et al., 2016). This is an example of how minimum living space standard increases with economic development and rising incomes. 
MALAYSIA Minimum requirement for 'public housing' in Kuala Lumpur (capital city of an upper middle income country) is currently 3 bedrooms and 60 square meters of floor space. This minimum requirement has increased over time along with Malaysia's economic development. It was 1 bedroom and 37 square meters from 1956 to 1981, 2 bedrooms and 52 square meters from 1982 to 1996, and 2 bedrooms and 52 square meters from 1997 to 1998 (Hadi, 2014).

HABITAT FOR HUMANITY Habitat for Humanity builds basic low-cost housing around the world that meets minimum international standards for healthy housing while using local materials and being consistent with local norms and conditions. This means that Habitat for Humanity floor plans can be a valuable source for determining minimum living space requirements for a living wage. We used the Habitat for Humanity floor plan for rural Malawi of 30 square meters to help determine the cost of decent housing for a living wage for this very poor country (Anker and Anker, 2013).

OTHER EXAMPLES A minimum of 30 square meters is used for government 'affordable housing for low income households' in Nigeria (lower middle income country). Around 40 square meters is used for government housing for 'low income households' in tea estate housing in Sri Lanka (lower middle income country). Around 50 square meters is the standard for 'low income housing' in Tunisia, 'affordable housing' in Mexico (upper middle income countries) and 'social housing' in Morocco (lower middle income country). Around 60 square meters is the minimum size allowed in Brazil (Sao Paulo). Around 70 square meters of living space is used for 'social housing' in United Kingdom and Ireland, and 90 square meters is used for 'public housing' in New York City.

SUMMARY AND GUIDELINES FOR AMOUNT OF FLOOR SPACE Based on government living space guidelines for lower income households, we suggest the following guidelines for floor space in lieu of a local government standard. However, since such guidelines are common, it is always best to make the effort to find a local standard.

- 30-36 square meters of living space for low income countries.

This standard is consistent with multiple examples in Table 5.3. This includes housing for farm workers and low income households in South Africa, low income households in urban India, social housing in Vietnam, and affordable housing for low income households in Nigeria. Furthermore, around 30 square meters for a family of 4 and 37 square meters for a family of 5 is implied by median floor area 
Table 5.3 Living space guidelines for lower income households, 16 countries

\begin{tabular}{|c|c|c|c|c|}
\hline Country & $\begin{array}{l}\text { Development } \\
\text { level }\end{array}$ & $\begin{array}{l}\text { Gross } \\
\text { National } \\
\text { Income } \\
\text { (GNI) per } \\
\text { capita in } \\
\text { PPP, } 2014\end{array}$ & $\begin{array}{l}\text { Income group } \\
\text { in country }\end{array}$ & $\begin{array}{l}\text { Living space } \\
\quad \text { (square } \\
\text { meters) }\end{array}$ \\
\hline Malawi (rural) & Low income & 790 & Low income households & 30 \\
\hline Kenya (urban) & Lower middle & 2,940 & $\begin{array}{l}\text { Low income households } \\
\text { Middle income } \\
\text { households }\end{array}$ & $\begin{array}{l}35 \\
53\end{array}$ \\
\hline Vietnam & Lower middle & 5,350 & $\begin{array}{l}\text { Social housing (low } \\
\text { income) }\end{array}$ & 30 \\
\hline India (urban) & Lower middle & 5,630 & $\begin{array}{l}\text { Low income households } \\
\text { Middle income } \\
\text { households } \\
\text { High income households }\end{array}$ & $\begin{array}{l}28-48 \\
48-80\end{array}$ \\
\hline $\begin{array}{l}\text { India } \\
\text { (Maharashtra) }\end{array}$ & & & Low income households & $28-45$ \\
\hline $\begin{array}{l}\text { India (Uttar } \\
\text { Pradesh) }\end{array}$ & & & Low income households & $29-50$ \\
\hline Nigeria & Lower middle & 5,710 & $\begin{array}{l}\text { Affordable housing } \\
\text { (low income) }\end{array}$ & 30 \\
\hline Morocco & Lower middle & 7,290 & $\begin{array}{l}\text { Social housing (low } \\
\text { income, less than } \\
\text { twice the minimum } \\
\text { wage) }\end{array}$ & 50 \\
\hline $\begin{array}{l}\text { Sri Lanka } \\
\quad \text { (tea estates) }\end{array}$ & Lower middle & 10,300 & Tea estates workers & 40 \\
\hline Tunisia & Upper middle & 11,020 & $\begin{array}{l}\text { Low income households } \\
\text { (1-2 minimum wage) }\end{array}$ & 50 \\
\hline $\begin{array}{l}\text { South Africa } \\
\text { (farm } \\
\text { workers) }\end{array}$ & Upper middle & 12,700 & Farm workers & 30 \\
\hline $\begin{array}{l}\text { South Africa } \\
\text { (urban) }\end{array}$ & & & $\begin{array}{l}\text { Low income } \\
\text { households }\end{array}$ & $\begin{array}{l}30-45 \\
\text { (36 average) }\end{array}$ \\
\hline $\begin{array}{l}\text { China } \\
\quad \text { (Shenzhen) }\end{array}$ & Upper middle & 13,170 & Low rent housing & $\begin{array}{l}44 \text { (for } 2-3 \\
\text { persons); } \\
57 \text { (for } 4+ \\
\text { persons) }\end{array}$ \\
\hline $\begin{array}{l}\text { Brazil } \\
\quad \text { (Sao Paulo) }\end{array}$ & Upper middle & 15,570 & Minimum size allowed & 60 \\
\hline $\begin{array}{l}\text { Mexico } \\
\quad \text { (urban) }\end{array}$ & Upper middle & 16,840 & Affordable housing & 50 \\
\hline
\end{tabular}


Table 5.3 (continued)

\begin{tabular}{lcclc}
\hline Country & $\begin{array}{l}\text { Development } \\
\text { level }\end{array}$ & $\begin{array}{c}\text { Gross } \\
\text { National } \\
\text { Income } \\
\text { (GNI) per } \\
\text { capita in } \\
\text { PPP, 2014 }\end{array}$ & $\begin{array}{l}\text { Income group } \\
\text { in country }\end{array}$ & $\begin{array}{c}\text { Living space } \\
\text { (square } \\
\text { meters) }\end{array}$ \\
\hline $\begin{array}{l}\text { Malaysia } \\
\text { (Kuala Lumpur) }\end{array}$ & Upper middle & 24,770 & Minimum size allowed & 60 \\
$\begin{array}{l}\text { United Kingdom } \\
\text { High income }\end{array}$ & 39,500 & $\begin{array}{c}\text { Social housing for } \\
\text { 4 persons (low } \\
\text { income) }\end{array}$ & 70 \\
$\begin{array}{c}\text { Ireland } \\
\text { USA }\end{array}$ & High income & 42,830 & $\begin{array}{c}\text { Social housing for 4 } \\
\text { persons (low income) }\end{array}$ & 73 \\
(New York City) & High income & 55,900 & $\begin{array}{c}\text { Public housing (low } \\
\text { income) }\end{array}$ & 90 \\
\hline
\end{tabular}

Notes: Values for Kenya and China assume that gross floor space is $12 \%$ more than living space. Value for Sri Lanka was reduced by roughly $20 \%$ based on our calculations from a floor plan.

Sources: $\quad$ Woetzel, Ram, Mishke, Garemo, Sankhe (2014), Anker and Anker (2014a), Republic of Kenya (2004), Government of India (2012), Maharashtra Housing and Area Development Authority (2014), Uttar Pradesh Housing and Development Board (2014), Vietnam Government (2005), Hadi (2014), Centre for affordable housing finance in Africa (2015), CABE (2010), Republic of South Africa (1997), Pottie (2003), Moolla, Kotz and Block (2011), Wang (2016), Thibbotuwawa (2016). GNI per capita from World Bank Development Indicators.

per person in cities in least developed countries according to United Nations (2000). 30-36 square meters is also consistent with living space in the Sustainable Agricultural Network/Rainforest Alliance standard (2005, p. 22) that requires ' 5 square meters of space per person in sleeping areas' for dormitory accommodation considering the need for more than sleeping areas for families.

- 36-60 square meters for middle income countries.

This range is consistent with many examples from Table 5.3. It is also consistent with median floor space found in Asia, Latin America and Caribbean and former socialist countries in East and Central Europe. This broad range allows leeway for researchers, although lower middle income countries would be usually in the 36-48 square meter range and upper middle income countries would usually be in the $48-60$ square meter range. 
- 70+ square meters for high income countries.

This is the standard used for social housing in the United Kingdom and Ireland. It is also consistent with median floor space in the European Union. This standard will be low, however, for some high income countries since 90 square meters is used for New York City public housing.

\subsection{Principles of Housing Standards for Estimating a Living Wage}

Table 5.4 presents international minimum acceptable housing standards (based mainly on housing principles in international conventions, covenants and recommendations) and indicates how housing standards are likely to differ between rural and urban areas in a country as well as how they are likely to change with economic development. These minimum standards need to be met by a local housing standard used to estimate a living wage.

Table 5.5 provides a template that researchers should use to determine and document an acceptable local housing standard for estimating a living wage. Column 1 lists characteristics of a housing standard, column 2 provides international minimum standards, and column 3 provides comments and examples of local standards. The local housing standard decided on should be entered in column 4. The local housing standard can be higher than the minimum international standard if local conditions are higher than the international minimum standards - but it should not be lower even if local conditions are worse.

\section{PART III. DEVELOPING A LOCAL HOUSING STANDARD}

The local standard for acceptable housing needs to meet both international minimal standards as well as local norms. Depending on data availability and study focus, this standard could be set for a city, region, rural areas, or urban areas in a country. For example, while an improved pit toilet close to the house is acceptable in rural Kenya, it is not acceptable in urban Vietnam where almost all houses have an indoor flush toilet. International housing standards call for adequate lighting, but do not require electricity because it is not always available. This means that electricity would not be required in locations where relatively few households have electricity. In contrast, a house without electricity would not be acceptable or decent in locations where most houses have electricity. 


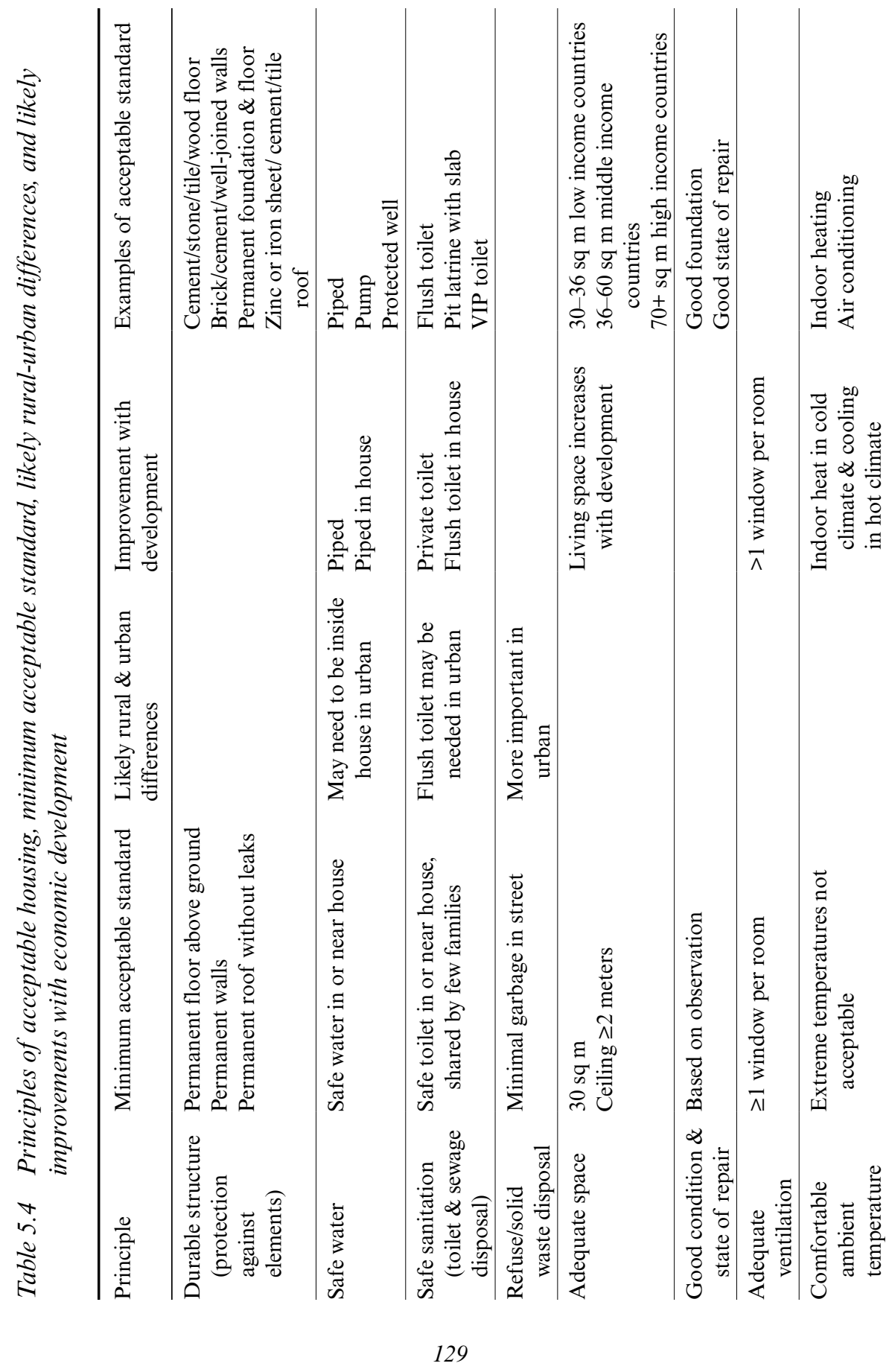




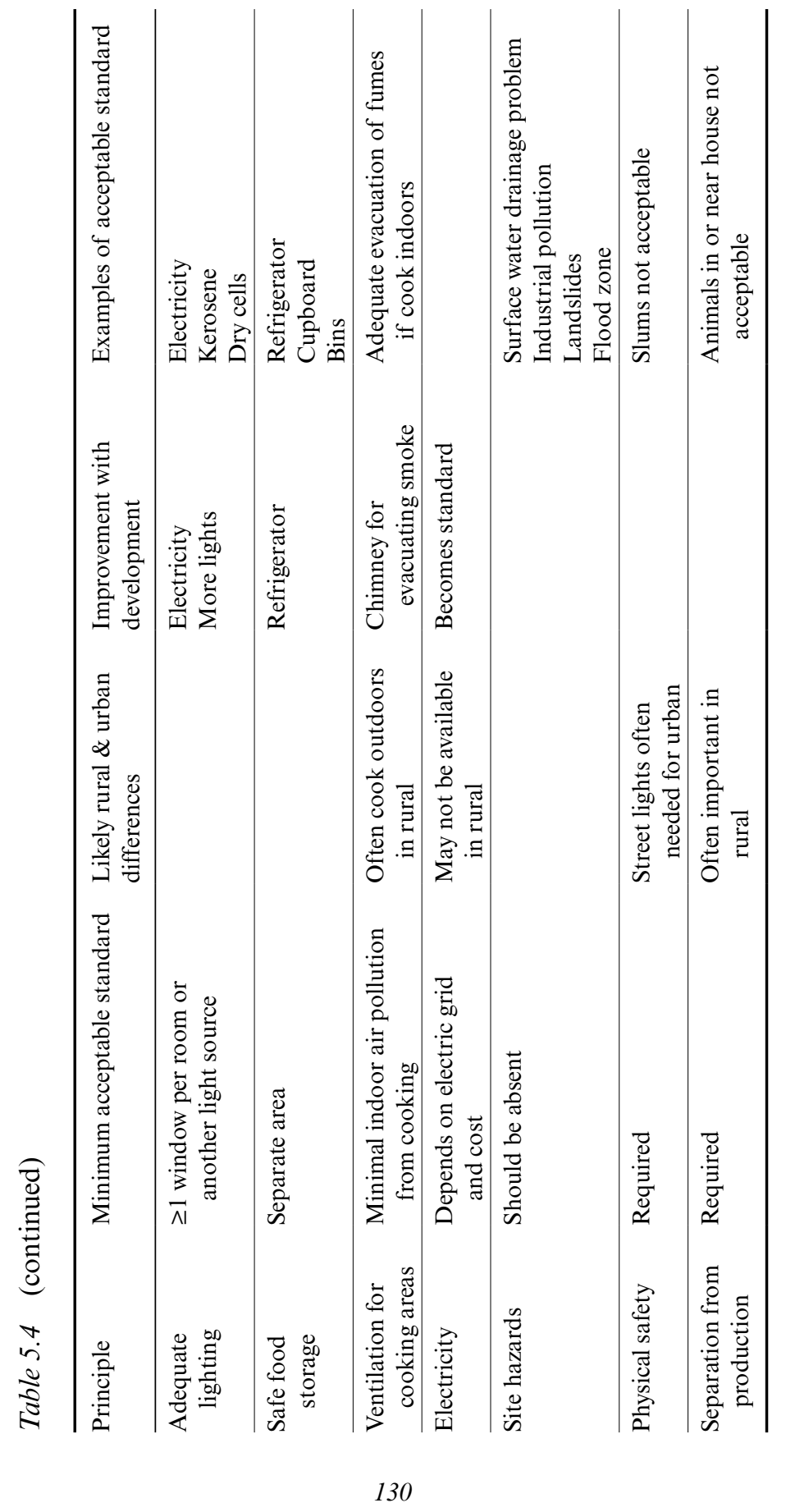


Table 5.5 Template to determine and describe local housing standard

\begin{tabular}{|c|c|c|c|}
\hline $\begin{array}{l}\text { Housing } \\
\text { characteristics }\end{array}$ & $\begin{array}{l}\text { International } \\
\text { minimum } \\
\text { standards }\end{array}$ & $\begin{array}{l}\text { Comments and } \\
\text { examples of possible } \\
\text { local standards }\end{array}$ & $\begin{array}{l}\text { Local standard } \\
\text { (common in } \\
\text { location \& meets } \\
\text { international } \\
\text { standard) }\end{array}$ \\
\hline \multicolumn{4}{|l|}{ Materials } \\
\hline Walls & $\begin{array}{l}\text { Durable material } \\
\text { providing } \\
\text { protection from elements }\end{array}$ & $\begin{array}{l}\text { Cement, stone, } \\
\text { baked bricks (can't } \\
\text { be mud, sticks, or } \\
\text { iron sheets) } \\
\end{array}$ & \\
\hline Roof & $\begin{array}{c}\text { Durable material } \\
\text { without leaks }\end{array}$ & $\begin{array}{l}\text { Corrugated iron } \\
\text { Tile } \\
\text { Cement } \\
\end{array}$ & \\
\hline Floor & Durable material & $\begin{array}{c}\text { Cement (can't be } \\
\text { mud or dung) }\end{array}$ & \\
\hline \multicolumn{4}{|l|}{ Amenities } \\
\hline Toilet & $\begin{array}{l}\text { At least pit latrine } \\
\text { with slab }\end{array}$ & $\begin{array}{l}\text { Pit latrine with slab, } \\
\text { VIP toilet, flush } \\
\text { toilet (can't be pit } \\
\text { latrine without slab) } \\
\end{array}$ & \\
\hline Water & $\begin{array}{l}\text { Safe water not far } \\
\text { from home }\end{array}$ & $\begin{array}{l}\text { Piped into dwelling } \\
\text { or yard, public tap, } \\
\text { borehole/tube well, } \\
\text { protected well (can't } \\
\text { be unprotected well) } \\
\end{array}$ & \\
\hline Electricity & Not required & $\begin{array}{l}\text { Requirement in } \\
\text { many locations }\end{array}$ & \\
\hline \multicolumn{4}{|c|}{ Ventilation \& lighting } \\
\hline $\begin{array}{l}\text { Ventilation } \\
\text { quality }\end{array}$ & \begin{tabular}{|c} 
Good ventilation - \\
especially important \\
when cook indoors
\end{tabular} & $\begin{array}{l}\text { Generally need } \\
\text { chimney when cook } \\
\text { indoors }\end{array}$ & \\
\hline Lighting & Adequate & & \\
\hline $\begin{array}{r}\text { Number of } \\
\text { windows }\end{array}$ & $\begin{array}{l}\text { Sufficient for } \\
\text { adequate lighting and } \\
\text { ventilation }\end{array}$ & & \\
\hline \multicolumn{4}{|l|}{ Living space } \\
\hline $\begin{array}{l}\text { Number of } \\
\text { square } \\
\text { meters of } \\
\text { living space } \\
\end{array}$ & $\geq 30 \mathrm{sq} \mathrm{m}$ & $\begin{array}{l}\text { Increases with } \\
\text { development } \\
\text { Might differ in rural } \\
\text { and urban areas } \\
\end{array}$ & \\
\hline $\begin{array}{l}\text { Number of } \\
\text { rooms }\end{array}$ & $\begin{array}{l}\leq 2 \text { persons per } \\
\text { room excluding } \\
\text { kitchen and toilet or } \\
\text { bath }\end{array}$ & $\begin{array}{l}\text { Number of } \\
\text { bedrooms standard } \\
\text { used in higher } \\
\text { income countries } \\
\end{array}$ & \\
\hline
\end{tabular}


Table 5.5 (continued)

\begin{tabular}{|l|l|l|l|}
\hline $\begin{array}{l}\text { Housing } \\
\text { characteristics }\end{array}$ & $\begin{array}{l}\text { International } \\
\text { minimum } \\
\text { standards }\end{array}$ & $\begin{array}{l}\text { Comments and } \\
\text { examples of possible } \\
\text { local standards }\end{array}$ & $\begin{array}{l}\text { Local standard } \\
\text { (common in } \\
\text { location \& meets } \\
\text { international } \\
\text { standard) }\end{array}$ \\
\hline $\begin{array}{l}\text { Kitchen } \\
\text { location }\end{array}$ & $\begin{array}{l}\text { If kitchen is inside } \\
\text { house, adequate ventilation } \\
\text { for cooking needed }\end{array}$ & $\begin{array}{l}\text { May be in separate } \\
\text { building in some } \\
\text { locations }\end{array}$ & $\begin{array}{l}\text { In good state } \\
\text { of repair }\end{array}$ \\
\hline Condition & $\begin{array}{l}\text { In good state } \\
\text { of repair }\end{array}$ & $\begin{array}{l}\text { In good state of } \\
\text { repair }\end{array}$ \\
\hline Environment & $\begin{array}{l}\text { Not a slum } \\
\text { as: surface water drainage, } \\
\text { industrial pollution, danger }\end{array}$ & & \\
\hline
\end{tabular}

Note that the local housing standard needs to be developed before local housing costs are collected in a local housing market survey (see Chapter 6), because this standard indicates the types of houses that need to be visited and costed during fieldwork.

\subsection{Secondary Data on Local Housing Conditions}

\subsubsection{Data from surveys and censuses}

Our methodology relies on secondary data to indicate local housing conditions. A variety of sources are usually available such as housing surveys, socio-economic household surveys, Demographic and Health Surveys (DHS), and population censuses. This also includes international databases such as World Bank World Development Indicators, CIA Factsheets, UNICEF, and UN-Habitat.

Table 5.6 provides a data collection form that can be used to record information on housing commonly found in secondary sources. This form should be adapted to reflect housing conditions in a study location. It provides a good starting point for developing a local housing standard. Information on housing characteristics should be recorded separately for rural and urban areas and location of interest whenever possible. 
Table 5.6 Example of form to record secondary data on local housing characteristics (adapt to local data available)

Source and year:

\begin{tabular}{|l|l|l|l|l|}
\hline Characteristics & $\begin{array}{l}\text { Urban } \\
\%\end{array}$ & $\begin{array}{l}\text { Rural } \\
\%\end{array}$ & $\begin{array}{l}\text { Location of } \\
\text { interest (when } \\
\text { possible) } \\
\%\end{array}$ & $\begin{array}{l}\text { Comments and } \\
\text { decisions on local } \\
\text { acceptable } \\
\text { standard for } \\
\text { each bolded } \\
\text { characteristic }\end{array}$ \\
\hline
\end{tabular}

Structure

\begin{tabular}{|l|l|l|l|l|}
\hline Permanent & & & & \\
\hline $\begin{array}{l}\text { Semi-permanent } \\
\text { (wall or roof not } \\
\text { permanent) }\end{array}$ & & & & \\
\hline $\begin{array}{l}\text { Temporary } \\
\text { (e.g. mud or } \\
\text { stick walls) }\end{array}$ & & & & \\
\hline
\end{tabular}

\section{Roof}

\begin{tabular}{|l|l|l|l|l|}
\hline Corrugated iron & & & & \\
\hline Concrete/tile & & & & \\
\hline Thatch & & & & \\
\hline Other (specify) & & & & \\
\hline
\end{tabular}

Floor

\begin{tabular}{|l|l|l|l|l|}
\hline Cement/tile & & & & \\
\hline Earth/dung & & & & \\
\hline Wood & & & & \\
\hline Other (specify) & & & & \\
\hline
\end{tabular}

Walls

\begin{tabular}{|l|l|l|l|l|}
\hline $\begin{array}{c}\text { Cement/stone/ } \\
\text { brick }\end{array}$ & & & & \\
\hline Wood & & & & \\
\hline $\begin{array}{c}\text { Mud/mud with } \\
\text { stone or stick }\end{array}$ & & & & \\
\hline Iron sheet & & & & \\
\hline Bamboo & & & & \\
\hline Other (specify) & & & & \\
\hline
\end{tabular}


Table 5.6 (continued)

Source and year:

\begin{tabular}{|l|l|l|l|l|}
\hline Characteristics & $\begin{array}{l}\text { Urban } \\
\%\end{array}$ & $\begin{array}{l}\text { Rural } \\
\%\end{array}$ & $\begin{array}{l}\text { Location of } \\
\text { interest (when } \\
\text { possible) } \\
\%\end{array}$ & $\begin{array}{l}\text { Comments and } \\
\text { decisions on local } \\
\text { acceptable standard } \\
\text { for each bolded } \\
\text { characteristic }\end{array}$ \\
\hline
\end{tabular}

\section{Electricity}

\section{Lighting source}

\begin{tabular}{|l|l|l|l|l|}
\hline Paraffin/kerosene & & & & \\
\hline Firewood & & & & \\
\hline Other (specify) & & & & \\
\hline
\end{tabular}

\section{Cooking fuel}

\begin{tabular}{|l|l|l|l|l|}
\hline Wood & & & & \\
\hline Charcoal & & & & \\
\hline Kerosene & & & & \\
\hline LPG & & & & \\
\hline Electricity & & & & \\
\hline Straw/grass & & & & \\
\hline Other (specify) & & & & \\
\hline
\end{tabular}

\section{Water source}

\begin{tabular}{|l|l|l|l|l|}
\hline Piped into house & & & & \\
\hline $\begin{array}{c}\text { Piped into dwelling } \\
\text { or yard }\end{array}$ & & & & \\
\hline Public tap & & & & \\
\hline Borehole/tube well & & & & \\
\hline Protected well & & & & \\
\hline Unprotected well & & & & \\
\hline $\begin{array}{c}\text { Unprotected spring/ } \\
\text { river/lake }\end{array}$ & & & & \\
\hline Rainwater & & & & \\
\hline Other (specify) & & & & \\
\hline Toilet facility & & & & \\
\hline Pit latrine with slab & & & & \\
\hline
\end{tabular}


Table 5.6 (continued)

Source and year:

\begin{tabular}{|l|l|l|l|l|}
\hline Characteristics & $\begin{array}{l}\text { Urban } \\
\%\end{array}$ & $\begin{array}{l}\text { Rural } \\
\%\end{array}$ & $\begin{array}{l}\text { Location of } \\
\text { interest (when } \\
\text { possible) } \\
\%\end{array}$ & $\begin{array}{l}\text { Comments and } \\
\text { decisions on local } \\
\text { acceptable standard } \\
\text { for each bolded } \\
\text { characteristic }\end{array}$ \\
\hline $\begin{array}{l}\text { Pit latrine without } \\
\text { slab/open pit }\end{array}$ & & & & \\
\hline VIP toilet & & & & \\
\hline Flush toilet & & & & \\
\hline No facility, bush & & & & \\
\hline Other (specify) & & & & \\
\hline Number of rooms (or number of bedrooms) & \\
\hline 1 & & & & \\
\hline 2 & & & \\
\hline 3 & & & \\
\hline $4+$ & \\
\hline
\end{tabular}

\subsubsection{Information from governments, local housing authorities, and local NGOs such as Habitat for Humanity}

As indicated above, national, state and local governments set building codes and pass laws that include minimum housing standards. Also, government housing departments and authorities often build or subsidize low-cost and affordable housing. Some NGOs, such as Habitat for Humanity, build basic housing for lower income families.

An effort should be made to find floor plans and housing standards used by governments and NGOs for low-cost and affordable housing. The local Rainforest Alliance office is also worth contacting, since it often has a locally adapted housing standard for accommodation on plantations and large farms. 


\subsection{Setting Local Housing Standard Using International Housing Standards and Local Housing Conditions and Norms}

The local housing standard for decent housing needs to meet minimum international standards as well as local housing conditions and norms. This means that while local housing standards can never be below international minimum standards they can and often are above.

The local housing standard should specify the following characteristics:

1. Acceptable construction materials for walls, roof and floor.

2. Acceptable amenities such as toilet, water, and electricity.

3. Acceptable living space (in terms of square meters or number of rooms).

4. Acceptable ventilation and lighting.

5. Acceptable environment (e.g. not located in a slum or hazardous area).

\subsubsection{Example: how to decide on acceptable construction materials for walls and floor}

Generally speaking, common construction materials used in a location that meet the international standards for durability should be used as the local housing standard for walls, floor, and roof. For example, suppose the distribution of construction material for walls in a location was $30 \%$ brick, $60 \%$ mud, and 10\% cement; and construction material for floors was $70 \%$ mud and $30 \%$ cement or tiles. While mud is the most common material for walls and floor, it does not meet international minimum standards. Brick should be selected for walls and cement or tiles selected for the floor because they are common and durable (and although cement would also be acceptable for walls, it is usually more expensive). Consequently, the local housing market survey would need to concentrate on houses with brick (or cement) walls and cement (or tile) floor.

\subsection{Examples of Setting Local Living Wage Housing Standards}

This section uses information from household surveys on housing conditions for the Dominican Republic and Malawi to illustrate how secondary housing data can be used to help set a local housing standard. These examples illustrate how very different housing conditions can be in rural and urban areas in developing countries. 
Table 5.7 Dominican Republic housing conditions in urban and rural areas according to household survey data and what should be local acceptable housing standards

\begin{tabular}{|c|c|c|c|}
\hline Characteristics & Urban & Rural & Comments about acceptable standard \\
\hline \multicolumn{4}{|l|}{ Roof } \\
\hline Zinc/corrugated iron & $52.0 \%$ & $82.1 \%$ & \multirow{2}{*}{$\begin{array}{l}\text { Either corrugated iron or cement/tile } \\
\text { acceptable standard in U \& R if } \\
\text { does not leak. }\end{array}$} \\
\hline Concrete/tile & 47.2 & 16.0 & \\
\hline \multicolumn{4}{|l|}{ Floor } \\
\hline Cement/tile & $97.9 \%$ & $91.2 \%$ & \multirow{4}{*}{$\begin{array}{l}\text { Cement/tile acceptable standard } \\
\text { in } U \& R \text { if not badly broken. }\end{array}$} \\
\hline Earth/dung & 1.5 & 7.5 & \\
\hline Wood & 1.9 & 0.6 & \\
\hline Other & 0.5 & 0.5 & \\
\hline \multicolumn{4}{|l|}{ Walls } \\
\hline Cement/stone/brick & $78.4 \%$ & $49.5 \%$ & \multirow{6}{*}{$\begin{array}{l}\text { Cement/stone/brick acceptable in U. } \\
\text { Cement/stone/brick acceptable } \\
\text { in R throughout country. } \\
\text { Wood acceptable if it is well joined } \\
\text { and not in hurricane zone. }\end{array}$} \\
\hline Wood planks & 17.2 & 38.1 & \\
\hline Palm & 1.4 & 8.2 & \\
\hline Iron sheet & 10.1 & 3.3 & \\
\hline Bamboo/wood \& mud & 8.8 & 48.7 & \\
\hline Other & 4.7 & 10.2 & \\
\hline \multicolumn{4}{|l|}{ Lighting source } \\
\hline Electricity & $99.5 \%$ & $89.8 \%$ & $\begin{array}{l}\text { Use electricity and kerosene as } \\
\text { standard for lighting in U. Use } \\
\text { kerosene or battery for R. }\end{array}$ \\
\hline \multicolumn{4}{|l|}{ Cooking fuel } \\
\hline LPG & $92.1 \%$ & $69.4 \%$ & \multirow[t]{4}{*}{ LPG acceptable standard in U \& R. } \\
\hline Firewood & & 18.2 & \\
\hline Charcoal & & 5.7 & \\
\hline No cooking facility & 4.6 & 6.3 & \\
\hline \multicolumn{4}{|l|}{ Water source } \\
\hline Piped into dwelling & $58.9 \%$ & $28.2 \%$ & \multirow{6}{*}{$\begin{array}{l}\text { Piped into dwelling acceptable } \\
\text { standard in U. } \\
\text { Piped into house or yard }\end{array}$} \\
\hline Piped into yard & 33.0 & 45.1 & \\
\hline Well & 2.1 & 10.0 & \\
\hline Truck delivery & 4.2 & 2.9 & \\
\hline Spring/river/creek & & 8.8 & \\
\hline Rainwater & & 3.9 & \\
\hline \multicolumn{4}{|l|}{ Drinking water source } \\
\hline Bottled water & $66.8 \%$ & $34.6 \%$ & \multirow{4}{*}{$\begin{array}{l}\text { Bottled water used in U \& R because } \\
\text { water in the Dominican Republic } \\
\text { generally not safe to drink. Include } \\
\text { cost of bottled water in housing } \\
\text { cost. }\end{array}$} \\
\hline Tap inside & 17.5 & 8.8 & \\
\hline Tap, public & see above & 22.0 & \\
\hline Well/spring & & 10.0 & \\
\hline
\end{tabular}


Table 5.7 (continued)

\begin{tabular}{lccc}
\hline Characteristics & Urban & Rural & Comments about acceptable standard \\
\hline Rain & & 17.5 & \\
Truck & 11.8 & 6.6 & \\
Toilet facility & & & \\
Indoor flush & $72.5 \%$ & $30.4 \%$ & Indoor private flush toilet \\
Indoor flush, shared & 5.7 & 1.8 & acceptable in U. \\
Pit latrine with seat & 17.6 & 53.7 & Flush toilet or pit latrine with seat \\
Pit latrine without seat & 1.7 & 5.7 & acceptable standard in R if clean \& \\
& & & with decent drainage and depth. \\
Consumer durables & & & \\
Refrigerator & $78.3 \%$ & $53.1 \%$ & Refrigerator norm in U \& R. \\
Washing machine & $75.6 \%$ & $54.7 \%$ & Washing machine norm in U \& R. \\
\hline
\end{tabular}

Source: Centro de Estudios Sociales y Deomgráficos (CESDEM), 2008.

\subsubsection{Example of urban and rural housing conditions that generally meet international standards at least on paper: Dominican Republic}

Housing conditions in the Dominican Republic meet or exceed minimum international housing standards according to household survey data. This is true for both rural and urban areas (Table 5.7). A majority of houses in both rural and urban Dominican Republic have a cement or corrugated iron roof; cement or tile floor; cement, brick or wood walls; electricity; water pipe in house or yard; flush toilet or pit toilet with seat; and refrigerator and washing machine. Despite this, we found when visiting housing in rural areas that many homes were not actually acceptable for decency. First, wood walls, which are common in rural Dominican Republic, are often so poorly joined that wind, rain and light easily pass through. Second, wood walls are not acceptable in the south of the country, because this is a hurricane zone and poorly constructed wood houses cannot withstand hurricane force winds. Third, cement foundations and cement floors of many houses we visited were in a deteriorated state. Fourth, we found that most pit toilets were in very poor condition with very poor drainage. This example illustrates why it is necessary to visit local housing to determine if houses are acceptable and so the cost of acceptable local housing. 
Table 5.8 Malawi housing conditions in rural and urban areas according to household survey data and what should be acceptable housing standards

\begin{tabular}{|c|c|c|c|}
\hline Characteristics & Urban (U) & Rural (R) & Acceptable standard \\
\hline \multicolumn{4}{|l|}{ Structure } \\
\hline $\begin{array}{l}\text { Permanent } \\
\text { (concrete/brick/zinc) }\end{array}$ & $56.7 \%$ & $23.5 \%$ & \multirow[t]{4}{*}{$\begin{array}{l}\text { Use international standard of } \\
\text { permanent structure for } U \& R\end{array}$} \\
\hline $\begin{array}{l}\text { Semi-permanent } \\
\text { (either wall or roof } \\
\text { not permanent) }\end{array}$ & 27.9 & 24.1 & \\
\hline $\begin{array}{l}\text { Temporary } \\
\text { (thatch roof \& } \\
\text { sundried bricks) }\end{array}$ & 15.4 & 52.4 & \\
\hline Roof & $\begin{array}{l}\text { Not } \\
\text { reported }\end{array}$ & & \\
\hline $\begin{array}{l}\text { Corrugated iron } \\
\text { Concrete/tile }\end{array}$ & & & \multirow[t]{2}{*}{$\begin{array}{l}\text { Use corrugated iron without } \\
\text { leaks in R \& U }\end{array}$} \\
\hline Thatch & & common & \\
\hline \multicolumn{4}{|l|}{ Floor } \\
\hline Cement/tile & $65.9 \%$ & $14.1 \%$ & \multirow[t]{2}{*}{ Use cement for $\mathrm{R} \& \mathrm{U}$} \\
\hline Earth/dung & 32.8 & 85.5 & \\
\hline Wall & $\begin{array}{l}\text { Not } \\
\text { reported }\end{array}$ & & \\
\hline $\begin{array}{l}\text { Cement/stone/brick } \\
\text { Wood planks } \\
\text { Stone \& mud }\end{array}$ & & & $\begin{array}{l}\text { Use international standard of } \\
\text { permanent walls in R \& U }\end{array}$ \\
\hline Electricity & $34.7 \%$ & $3.5 \%$ & $\begin{array}{l}\text { Electricity could be standard in } \\
\text { U. Electricity not standard in R. }\end{array}$ \\
\hline \multicolumn{4}{|l|}{ Lighting source } \\
\hline Electricity & $32.6 \%$ & $2.9 \%$ & $\begin{array}{l}\text { Possibly use electricity as standard } \\
\text { for lighting in U. Not in R. }\end{array}$ \\
\hline Paraffin/kerosene & 42.5 & 53.5 & \multirow{4}{*}{$\begin{array}{l}\text { Use kerosene or battery for } \mathrm{R} \\
\text { depending on cost and } \\
\text { availability }\end{array}$} \\
\hline Firewood & 0.7 & 8.9 & \\
\hline Battery & 8.8 & 30.8 & \\
\hline Candle & 15.2 & 2.7 & \\
\hline \multicolumn{4}{|l|}{ Cooking fuel } \\
\hline Firewood & $58.2 \%$ & $94.1 \%$ & \multirow{4}{*}{$\begin{array}{l}\text { Use firewood as standard in R. } \\
\text { Use either charcoal or firewood } \\
\text { in } U \text { as standard depending on } \\
\text { availability and cost. }\end{array}$} \\
\hline Charcoal & 36.7 & 3.7 & \\
\hline Electricity & 9.2 & 0.2 & \\
\hline Other & 0.9 & 1.9 & \\
\hline
\end{tabular}


Table 5.8 (continued)

\begin{tabular}{|c|c|c|c|}
\hline Characteristics & Urban (U) & Rural (R) & Acceptable standard \\
\hline \multicolumn{4}{|l|}{ Water source } \\
\hline $\begin{array}{l}\text { Piped into dwelling } \\
\text { or yard }\end{array}$ & $31.0 \%$ & $1.8 \%$ & \multirow{2}{*}{$\begin{array}{l}\text { Use piped into dwelling or yard } \\
\text { as standard for U or possibly } \\
\text { public tap if close by. }\end{array}$} \\
\hline Public tap & 45.3 & 10.1 & \\
\hline Borehole/tube well & 12.8 & 58.8 & \multirow{4}{*}{$\begin{array}{l}\text { Use any water source that is safe } \\
\text { and within reasonable distance } \\
\text { to house as standard for R. }\end{array}$} \\
\hline Protected well & 3.4 & 6.0 & \\
\hline Unprotected well & 6.2 & 17.1 & \\
\hline Unprotected spring & 0.8 & 2.3 & \\
\hline \multicolumn{4}{|l|}{ Toilet facility } \\
\hline Pit latrine with slab & $8.3 \%$ & $4.0 \%$ & \multirow{5}{*}{$\begin{array}{l}\text { Use pit latrine with slab or VIP } \\
\text { toilet as standard in R \& U } \\
\text { if clean and with acceptable } \\
\text { drainage and depth. }\end{array}$} \\
\hline $\begin{array}{l}\text { Pit latrine without } \\
\text { slab/open pit }\end{array}$ & 61.9 & 77.5 & \\
\hline VIP toilet & 1.5 & 1.6 & \\
\hline Flush toilet & 1.6 & 0.4 & \\
\hline No facility, bush & 2.4 & 12.5 & \\
\hline \multicolumn{4}{|l|}{ Consumer durables } \\
\hline Refrigerator & $15.7 \%$ & $1.3 \%$ & Refrigerator not norm in $\mathrm{U}$ or $\mathrm{R}$. \\
\hline
\end{tabular}

Source: Demographic and Health Survey, National Statistical Office, Zomba, Malawi and ICF Macro (2010).

\subsubsection{Example of poor local housing conditions and so need to base acceptable housing standards mainly on international minimum standards: Rural Malawi}

Data from the Malawi 2010 Demographic and Health Survey indicate that housing conditions are very poor in rural Malawi (Table 5.8). Only 14\% of rural houses in Malawi have a cement floor; only 24\% have a corrugated iron roof and cement or brick walls; only $7 \%$ have an improved toilet; and only 3\% have electricity. Housing standards in rural Malawi are so poor that a local housing standard for a rural living wage needs to be based mainly on international minimum standards.

\section{NOTES}

1. Even the United Nations' Standard Minimum Rules for the Treatment of Prisoners (1957) includes standards for prisoner accommodations: 'Cells and prison dormitories shall provide adequate space, ventilation, lighting and sanitary facilities and are to be kept clean at all times.' 
2. UN-Habitat (2003) found that 21 of 30 cities they studied had an official definition of a slum, and 28 of 30 cities had a widely used unofficial definition.

3. A room is defined as a space in a housing unit or other living quarters enclosed by walls reaching from the floor to the ceiling or roof covering, or to a height of at least 2 meters, or an area large enough to hold a bed for an adult that is at least 4 square meters' (OECD, Glossary of statistical terms. Available at https://stats.oecd.org/glossary/detail. asp?ID=2363. Accessed 8 July 2016).

4. Acceptable number of rooms is not affected by age and sex of family members, since UK law assumes that children above age 10 can sleep with their same sex parent (United Kingdom Housing Act, 1985).

5. Ireland defines overcrowding as: "number of persons sleeping in the house and the number of rooms therein - are such that any two of those persons, being persons of ten years of age or more of opposite sexes and not being persons living together as husband and wife, must sleep in the same room' (Ireland, Office of the Attorney General, 1966).

6. The most common measure of affordable housing, that no more than $30 \%$ of household income can be for housing, can be traced back to US National Housing Act of 1937 (Schwartz and Wilson, undated; Woetzel et al., 2014).

7. The following example demonstrates that a minimum of around $10 \%$ of covered space is lost to internal and external walls. Take a simple 10 meter by 10 meter house (100 square meters covered space) with 2 internal walls that divide this house into 4 equal size rooms. If internal walls are 10 centimeters ( 4 inches) thick and external walls are 20 centimeters thick ( 8 inches), which are common thicknesses, around $10 \%$ of the covered space would consist of internal and external walls ( 2 meters of internal wall area and 8 meters of external wall area).

8. Typical LIG houses in India include a small living/sitting room, small kitchen, small toilet room, small bathing area, and 1 or 2 bedrooms.

9. Point 8 is concerned with 'housing accommodation for single workers or workers separated from their families [when this] is collective' (ILO Recommendation No. 115). 


\section{APPENDIX 5.1 SUMMARY OF DEFINITIONS AND PRINCIPLES OF ADEQUATE HOUSING OF INTERNATIONAL ORGANIZATIONS}

\section{International Covenant on Economic, Social and Cultural Rights}

General Comment 4 on the Right to Adequate Housing in Article 11(1) of The International Covenant on Economic, Social and Cultural Rights (Office of the High Commissioner for Human Rights, 1991) is specific about what is meant by adequate housing:

While adequacy is determined in part by social, economic, cultural, climatic, ecological and other factors, the Committee believes that it is nevertheless possible to identify certain aspects of right that must be taken into account for this purpose in any particular context. They include the following:

(a) Legal security of tenure . . legal protection against forced eviction, harassment and other threats ...

(b) Availability of services, materials, facilities and infrastructure ... access to natural and common resources, safe drinking water, energy for cooking, heating and lighting, sanitation and washing facilities, means of food storage, refuse disposal, site drainage and emergency services . . .

(c) Affordability ... should be at a level that the attainment and satisfaction of other basic needs are not threatened or compromised . . .

(d) Habitability . . . adequate space and protection from cold, damp, heat, rain, wind or other threats to health, structural hazards, and disease vectors. The physical safety of occupants must also be guaranteed. . .

(e) Accessibility ... must be accessible to those entitled to it ... such as disadvantaged groups ...

(f) Location ... allows access to employment options, health care services, schools, child care centers, and other social facilities . . . housing should not be built on polluted sites nor in immediate proximity to pollution sources

(g) Cultural adequacy ... enable the expression of cultural identity and diversity of housing.

\section{UN-Habitat}

UN-Habitat developed a set of indicators to measure and monitor the state of the world's cities and in the progress of countries in reducing the number of people living in urban slums as part of the monitoring of poverty and Millennium Development Goals. Slums were defined by UN-Habitat (2013) as households that lacked either improved water, improved sanitation, sufficient living area (more than three persons per room), or durable housing. In 2012, 32.7\% of urban households in developing regions lived 
in a slum according to UN-Habitat. This ranged from $13.3 \%$ in Northern Africa to $35.0 \%$ in South Asia and 61.7\% in Sub-Sahara Africa.

The following definitions were used by UN-Habitat (2009) for the four elements included in its definition of a slum in addition to secure tenure.

- Access to safe water needs to be affordable (less than $10 \%$ of household income), available in sufficient quantity (at least 20 liters per person per day), and available without excessive physical efforts and time (less than 1 hour per day for minimum sufficient quantity). The following types of supply for drinking water in urban areas are considered acceptable: 'piped water into dwelling, plot or yard; public tap/standpipe; borehole/tube well; protected dug well; protected spring; rainwater collection and bottled water ... where there is a secondary source of improved water for other uses such as personal hygiene and cooking' (p. 15).

- Access to improved sanitation facilities requires a toilet facility to be correctly constructed and maintained; shared by maximum of two households; and with septic system with sufficient capacity not to be clogged. The following toilet facilities are considered acceptable in urban areas: 'flush/pour-flush toilets or latrines connected to a sewer, septic tank or pit; ventilated improved pit latrine; pit latrine with slab or platform of any material which covers the pit entirely except for drop hole; and compositing toilets/latrines provided they are not public' (p. 16).

- Overcrowding and sufficient living area defined as more than three persons per room with 'a room defined as a space in a housing unit or other living quarters ... of an area large enough to hold a bed for an adult, that is at least four square meters. The total number of types of rooms therefore includes bedrooms, dining rooms, living rooms, studies, habitable attics, servants' room, kitchen and other separate spaces intended for dwelling purposes' (p. 9).

- Durable housing is defined as 'a housing unit built on a nonhazardous location and has a structure permanent and adequate enough to protect its inhabitants from the extreme of climatic conditions such as rain, heat, cold, humidity. The following locations are considered hazardous: housing settled in geologically hazardous zones (landslides/earthquake and flood areas); garbage mountains; high industrial pollution areas; other high risk zones (e.g. railroads, airports, energy transmission lines). The following durability factors are considered when categorizing housing units: quality of construction (e.g. materials used for wall, floor and roof); compliance with local building codes, standards and by-laws' (p. 8). 


\section{International Labour Organization Recommendation No. 115 (1961) Concerning Workers' Housing}

International Labour Organization passed a Recommendation Concerning Workers' Housing in 1961 that specifies housing standards. 'As a general principle', housing should have 'structural safety and reasonable levels of decency, hygiene and comfort'. This Recommendation includes 'Suggestions Concerning Methods of Application' (underlining added for emphasis):

General Principles [of housing standards] should relate in particular to -

7(a) the minimum space per person or per family as expressed in terms of one or more of the following, due regard being had to the need for rooms of reasonable dimensions and proportions:

(i) floor area;

(ii) cubic volume; or

(iii) size and number of rooms;

7(b) the supply of safe water in the workers' dwelling in such ample quantities as to provide for all personal and household uses;

7(c) adequate sewage and garbage disposal systems;

7(d) appropriate protection against heat, cold, damp, noise, fire, and diseasecarrying animals, and, in particular, insects;

7 (e) adequate sanitary and washing facilities, ventilation, cooking and storage facilities and natural and artificial lighting;

$7(\mathrm{f})$ a minimum degree of privacy both -

(i) as between individual persons within the household; and

(ii) for the members of the household against undue disturbance by external factors; and

$7(\mathrm{~g})$ suitable separation of rooms devoted to living purposes from quarters for animals. ...

8. ${ }^{9}$ Workers' housing standards should be revised from time to time to take account of social, economic and technical development and increases of real income per head.

9. In general, and in localities where employment opportunities are not of a temporary character, workers' housing and related community facilities should be of durable construction.

10. The aim should be to construct workers' housing and related community facilities in the most suitable materials available, having regard to local conditions, such as liability to earthquakes.

\section{World Health Organization Principles of Healthy Housing}

WHO has six principles for health aspects of adequate housing (WHO, 1989). The following describes the first three principles which are particularly relevant for living wage. 


\section{Protection against communicable diseases}

The following conditions are necessary to ensure protection against communicable diseases in WHO's Health Principles of Housing (WHO, 1989).

\section{- Safe and adequate water supply}

The water supply should be either inside or relatively close to the dwelling. 'An adequate supply of safe and potable water assists in preventing the spread of gastrointestinal diseases, supports domestic and personal hygiene and provides and improved standard of living' (pp. 2-3). And 'having to carry water from a distance almost always means that there will be inadequate quantities in the home and an added risk of contamination' (p. 3).

\section{- Sanitary disposal of excreta and adequate toilets}

'Sanitary disposal of excreta [which] reduces the faecal-oral transmission of disease and the breeding of insect vectors' (p. 4) is required. Note that 'Contamination may occur near houses, as when people defecate on the ground or in areas where food is grown, or when latrines are improperly located in relation to wells, set in soil lacking satisfactory drainage, or inadequately maintained ... These hazards are worse in conditions of overcrowding, whether in slums, peri-urban settlements or temporary camps, where facilities for excreta disposal are absent, insufficient or badly maintained' (p. 4)

\section{- Disposal of solid wastes}

'Adequate and safe disposal of solid domestic wastes reduces health risks and helps to provide a more pleasant living environment; appropriate methods of storage and disposal discourage insect and rodent vectors of disease and protect people against poisonous substances and objects likely to cause accidental injury' (p. 5). According to WHO (1989), hazards associated with inadequate and unsafe disposal of solid waste 'increase with urbanization and economic development, as consumption becomes more varied' (p. 5).

\section{- Drainage of surface water}

'Efficient drainage of surface waters helps to control communicable diseases, safety hazards, and damage to homes and property' (p. 6). Breeding sites for vectors such as mosquitoes need to be prevented. Special attention is required as regards 
drainage near wells, latrines and kitchens. 'Inadequate drainage of surface waters - including domestic wastewater - results in pools or muddy and marshy areas that provide breeding places for mosquitos, flies and other insect vectors of disease. Standing waters near wells, latrines and kitchens are of special concern, as they are important loci of biological contamination' (p. 6).

\section{- Personal and domestic hygiene}

'Adequate housing includes facilities for personal and domestic hygiene' (p. 6). Stables for animal husbandry should be at a reasonable distance from the house. 'Rural families engaged in animal husbandry are exposed to special hazards. The faeces and urine of animals kept inside dwellings may harbour pathogens and increase the difficulty of maintaining cleanliness, thus increasing exposure to insect and animal disease vectors. Stabling must be at a distance from dwellings and pets must be kept pest-free in order to reduce the transmission of disease, especially to children' (p. 7).

\section{- Safe food preparation and storage}

'Healthy dwellings provide facilities for the safe preparation and storage of food, so that householders can employ sanitary food handling practices' (p. 7).

\section{- Structural safeguards against disease transmission}

'Adequate housing provides structural safeguards against transmission of disease, including enough space to avoid overcrowding. Dirt floors not only make domestic hygiene difficult, but may harbor helminths. .. . Overcrowding, particularly in conjunction with poverty and inadequate facilities, have been shown to increase the transmission rates of such communicable diseases as tuberculosis, pneumonia, bronchitis and gastrointestinal infections' (p. 8).

\section{Protection against injuries, poisonings, and chronic disease}

\section{- Structural features and furnishing}

'The proper sitting, structure and furnishing of dwellings protects health, promotes safety and reduces hazards' (p. 9). WHO emphasizes the importance of durable structures that provide 'safe, dry, comfortable abode that shelters residents against 
vermin, extremes of temperature and recurring hazards of nature' (p. 9).

- Indoor air pollution

'Adequately designed, constructed and ventilated dwellings, free of toxic and irritating substances, reduce the risks of chronic respiratory diseases and malignancies' (p. 11). WHO recognizes that 'by far the most common problems arise from fuel combustion inside dwellings, whether from inadequate venting of heating and cooking devices or from the burning of biomass fuels (firewood, charcoal, crop residues, animal dung) in open fires' (p. 11).

- Chemical safety

'Sensible precautions in the household reduce exposure to hazardous chemicals' (p. 12).

- Use of home as a workplace

'Where a dwelling is also used as a workplace, those who live in it should be protected against hazards and contamination' (p. 12).

- Adequate separation of stabling and working premises from living areas

\section{Reducing psychological and social stresses to a minimum}

This principle emphasizes the concept of the home as a refuge and the psychological and social stress that come from 'overcrowding in dwellings, uncertainty of tenure, excessive noise, the struggle for survival, fear of crime and other threats to physical security' (p. 14). WHO notes that 'such stresses are all the greater for those ... who are making the transition from rural to urban life' (p. 14). 